\title{
Pathogenic Haemoparasites and Antibody to Newcastle Disease Virus from Apparently Healthy Wild Birds in Zaria, Nigeria
}

\author{
S B Oladele*, S J Enam ${ }^{1}$, O O Okubanjo ${ }^{2}$ \\ Department of Veterinary Pathology and Microbiology, \\ Faculty of Veterinary Medicine, Ahmadu Bello University, Zaria, Nigeria \\ 1. E-mail: yaxj5@yahoo.com, 2. Department of Veterinary Parasitology and Entomology, Faculty \\ of Veterinary Medicine, Ahmadu Bello University, Zaria, Nigeria. E-mail: sokubanjo2002@yahoo.com \\ *Corresponding author email: drbsunday@yahoo.com, Tel. +2348023672720 \\ Received: 04-05-2011, Accepted: 16-06-2011, Published Online: 17-11-2011 \\ doi: $10.5455 /$ vetworld.2012.13-18
}

\begin{abstract}
A total of ninety-eight wild birds, comprising eleven different species were captured alive from Zaria environs. These birds were used for the study, to determine the possible role they play as reservoirs of blood parasites. Thin blood smears (TBS) were prepared from the blood samples collected from these wild birds. The slides were stained and viewed under the microscope for the identification of blood parasites. Values of packed cell volume $(\mathrm{PCV})$, haemoglobin $(\mathrm{Hb})$ and total protein $(\mathrm{TP})$ were also determined from the blood samples. Sera from the birds were used for the determination of haemagglutination inhibition (HI) antibody titres to Newcastle disease virus (NDV). Haemoparasites, such as Plasmodium circumflexum, P. relictum, P. nouxi, Haemoproteus nisi, $H$. columbae, and Aegyptienella pullorum were identified from the blood of some of the wild birds. The highest mean HI antibody titre to Newcastle disease virus( NDV) $\left(\log _{2} 9.50 \pm 0.1\right)$ and lowest mean HI antibody titre to NDV ( $\log _{2} 2.50 \pm 1.7$ ) were obtained from Senegal parrot (Poicephalus senegalus) and Northern red bishop (Euplectes franciscanus), respectively. The highest mean PCV and Hb values of $49.00 \pm 0.01 \%$ and $16.30 \pm$ $0.1 \mathrm{~g} \%$, respectively were obtained from Senegal parrot (Poicephalus senegalus), while the lowest mean PCV and $\mathrm{Hb}$ values of $36.50 \pm 8.35 \%$ and $12.18 \pm 2.77 \mathrm{~g} \%$, respectively were recorded from African marsked weaver (Ploceus velatus). The highest mean TP value $(7.00 \pm 0.01 \mathrm{~g} / \mathrm{dl})$ and lowest mean TP value $(1.88 \pm 0.54 \mathrm{~g} / \mathrm{dl})$ were obtained from Laughing dove (Streptopelia senegalensis) and Zebra waxbill (Sporaeginthus subflavus), respectively. It was concluded that wild birds could serve as reservoirs of haemoparasites and viral pathogens which could be potential dangers to domestic birds in Zaria, Nigeria.
\end{abstract}

Key words: Haemoparasites, Viral pathogens, Wild birds, Antibody, Nigeria.

\section{I ntroduction}

Birds are widely distributed worldwide. They are found in all the seven continents. They live and breed in most terrestrial habitats. It is believed that the highest bird diversity occurs in tropical regions of the world. It was earlier thought that high diversity was the result of higher speciation rates in the tropics (Newton, 2003; Clements, 2007). However, recent studies have found higher speciation rates in the high latitudes that were offset by greater extinction rates than in the tropics (Weir and Schluter, 2007).

Birds are the largest sources of animal protein eaten by humans. Domestic birds, such as chickens, turkeys, ducks and geese account for much of human poultry consumption in most parts of the world (Gill, 2006; Clements, 2007).

Some species of wild birds are also of economic important, mostly as sources of food required through hunting. The species of wild birds commonly hunted for food include pheasant, wild turkeys, quails, doves, partridges, wild geese, guinea fowls and woodcocks (Keane et al., 2006; Clements, 2007), while songbirds and parrots could be used as pet birds. Other commercially valuable products from birds include feathers which are used as insulation in clothing and bedding (Chamberlain et al., 2005; Walther and Clayton, 2005).

Many land, shore and water birds undertake annual long distance migrations that is usually 
Pathogenic Haemoparasites and Antibody to Newcastle Disease from Apparently Healthy Wild Birds in Zaria,

triggered by the length of day light as well as weather conditions, thereby optimising availability of food sources and breeding habitat (Berthold et al., 2001; Shaffer et al., 2006; Clements, 2007). During migration, wild birds can disperse infectious agents across their migratory routes, and myriad pathogens harmful to poultry or other vertebrates have been associated with them (Dhama et al., 2008). For example, wild birds have been incriminated in spreading pathogens responsible for diseases, such as psittacosis, salmonellosis, campylobacteriosis, avian tuberculosis, avian influenza, Newcastle disease et cetera over a long distance (Oladele et al., 1999; Hubalek, 2004; Spottiswoode and Colebrook-Robjent, 2007). They can also harbour haemoparasites, such as Plasmodium species which can be transmitted to other birds or animals through vectors. For efficient dispersal of pathogens, therefore, wild birds could serve as reservoirs of micro-organisms or mechanical dispersers of vectors that harbour pathogens.

Because of the role of wild birds in harboring pathogens responsible for poultry diseases, it is very important that we screen their blood for haemoparasites and viral antibody that are of economic importance.

The aims of the study were to determine the presence of haemoparasites; NDV HI antibody titres; and the values of PCV, $\mathrm{Hb}$ and TP from the blood of some wild birds in Zaria environs.

\section{Materials and Methods}

Site of experiment: The study was carried out in Zaria, Northern Nigeria $\left(11^{\circ} 10^{\prime} \mathrm{N} ; 07^{\circ} 38^{\prime} \mathrm{E}\right)$. Trees and grasses characterize the vegetation of this zone with average rainfall, ranging from $1000 \mathrm{~mm}$ to $1250 \mathrm{~mm}$, and temperature of $17^{\circ} \mathrm{C}$ to $33^{\circ} \mathrm{C}$ (Sa'idu et al., 1994).

Experimental birds: A total of ninety-eight wild birds, belonging to eleven species were used. They include the Laughing dove (Streptopedia senegalensis), Northern red bishop (Euplectes frascisca), Zebra wax bill (Sporaeginthus subflavus), Village weaver (Ploceus cycullatus), African silver bill (Euodice cantans), Cut-throat finch (Amadina fasciata), Senegal parrot
(Poicephalus senegalus), African thrush (Tordus pelios), African masked weaver (Ploceus velatus), Alleys galinue (Porphyrio alleni) and Scally-fronted weaver (Sporofipes fronterlis).

The birds were captured alive with the aid of net traps which were placed at different locations in Zaria environs so as to evenly sample the birds. After the birds were captured they were taken to the Department of Biological Sciences, Ahmadu Bello University, Zaria for identification.

Clinical examination and blood sampling: After identification, the birds were examined individually for any lesions on their bodies. Each species of bird was kept in different cages and observed for three to five days before blood sampling. Millets, insects and water were provided ad libitum.

Blood sampling was through wing venepuncture, using 23 gauge sterile hypodermic needles and syringes. Blood for haematological parameters were collected into labeled Bijou bottles, containing ethylene diamine tetra acetic acid (EDTA) as anticoagulant. Blood samples for serum analysis were taken without anticoagulant. The serum samples were separated by centrifugation at $1,000 \mathrm{~g}$ for 10 minutes and stored frozen in plastic vials until laboratory determinations were carried out.

Laboratory procedures: Thin blood smear technique was carried out according to the standard procedures of Thrall (2004). The PCV, $\mathrm{Hb}$ and TP concentrations were determined by routine laboratory procedures of Benjamin (1985). Newcastle disease virus HI antibody quantification was performed using haemagglutination (HA) and HI procedures of Beard (1989): Two-fold dilutions of $50 \mu \mathrm{l}$ of the sera were made in phosphate buffered saline ( $\mathrm{pH}$ 7.2), and four haemagglutinaition (4HA) units of LaSota virus antigen in $50 \mu 1$ of $1 \%$ erythrocytes suspension were added to each well of the microtitre plate and left for 45 minutes at room temperature (26$30^{\circ} \mathrm{C}$ ). The HI titre for each serum sample was determined at the highest dilution of serum which causes complete inhibition of 4HA units.

Statistical analysis: All the data obtained were subjected to statistical analysis using Student's t- 

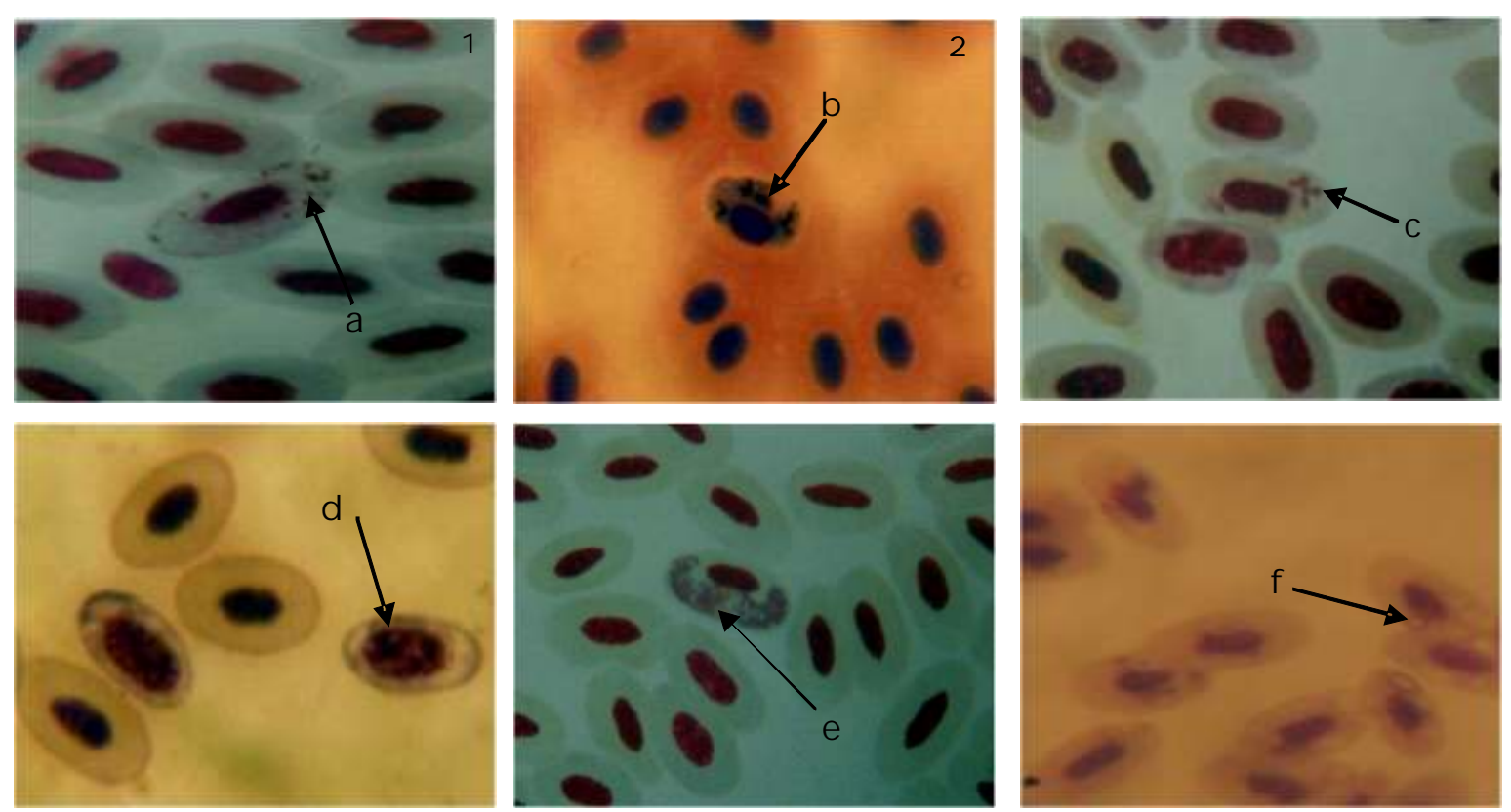

Figure-1: Plasmodium circumflexum (arrow head a) in the RBC of African masked weaver (Ploceus velatus) $\times 100$

Figure-2: Plasmodium relictum (arrow head b) in the RBC of Cut-throat finch(Amadina fasciata) $\times 100$

Figure-3: Plasmodium nouxi (arrow head c) in the RBC of Laughing dove (Streptopelia senegalensis) $\times 100$

Figure-4: Haemoproteus nisid (arrow head d) in the RBC of African silver bill (Euodice cantans) $\times 100$

Figure-5: Haemoproteus columbae,(arrow head e) in the RBC of Laughing dove (Streptopelia senegalensis) $x 100$.

Figure-6: Aegyptianella pullorum (arrow head f) in the RBC of Senegal fire finch (Lagonostica senegala) $\times 100$.

test analysis. Values of $(\mathrm{P}<0.05)$ were considered significant.

\section{Results}

Senegal parrot (Poicephalus senegalus) has the highest NDV HI antibody titre of $\log _{2} 9.50 \pm$ 0.1 , followed by Cut-throat finch (Amadina fasciata) with NDV HI antibody titre of $\log _{2} 8.10$ \pm 1.0 and Alleys galinue (Porphyrio alleni) with NDV HI antibody titre of $\log _{2} 6.00 \pm 0.1$. The lowest NDV HI antibody titre of $\log _{2} 2.50 \pm 1.7$ was recorded from Northern red bishop (Euplectes franciscanus) (Table 1).

The highest values of $\mathrm{PCV}$ and $\mathrm{Hb}$ of 49.00 $\pm 0.01 \%$ and $16.30 \pm 0.1 \mathrm{~g} \%$, respectively were recorded from Senegal parrot (Poicephalus senegalus). On the other a hand, the lowest values of $\mathrm{PCV}$ and $\mathrm{Hb}$ of $36.50 \pm 8.35 \%$ and $12.18 \pm 2.77 \mathrm{~g} \%$, respectively were recorded from African silver bill (Euodice cantans) (Table 1).

Zebra waxbill (Sporaeginthus subflavus) had the lowest TP value of $1.88 \pm 0.5 \mathrm{~g} / \mathrm{dl}$, while the highest TP value of $7.00 \pm 0.01 \mathrm{~g} / \mathrm{dl}$ was recorded from Laughing dove (Streptopelia senegalensis) (Table 1).

\section{Discussion}

In this study, $P$. circumflexum, $P$. relicum and $P$. nouxi were found in the blood of some of the wild birds sampled. It has been established that Plasmodium circumflexum and $P$. relicum which infect primarily the passerine birds can also infect domestic fowls or be experimentally transmitted to them; and the pathologic effects of these organisms in avian hosts range from no apparent signs to severe anaemia and death (Bennett et al., 1974; Springer, 1997; Valkiu-Nas, 2005).

The birds harbouring these blood parasites in this study were apparently healthy without any sign of anaemia. This is evidenced by mean range of PCV of $36.50 \pm 8.35 \%-49.00 \pm 0.01 \%$; and mean range of $\mathrm{Hb}$ of $12.18 \pm 2.77 \mathrm{~g} \%-16.30 \pm$ $0.1 \mathrm{~g} \%$. The values of these blood parameters were within the established normal values for both wild and domestic birds (Balash et al., 1973; 
Pathogenic Haemoparasites and Antibody to Newcastle Disease from Apparently Healthy Wild Birds in Zaria,

Table-1. Mean values of packed cell volume, haemoglobin, total protein and New castle disease virus antibody titre of different species of wild birds in Zaria (Mean \pm SE)

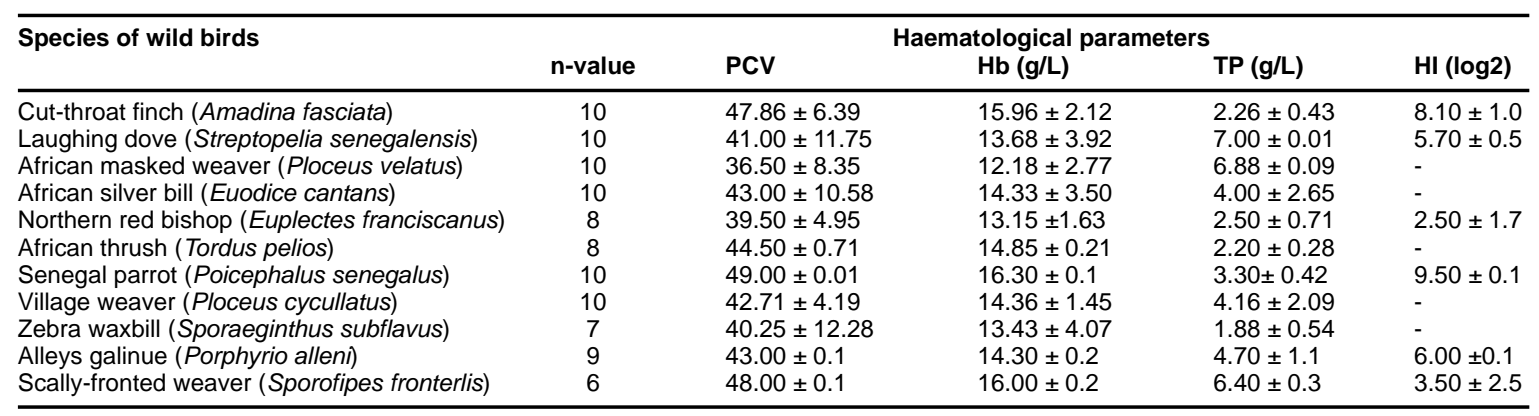

Campbell and Coles, 1986; Thrall, 2004; Oladele, 2009).

In this study, Haemoproteus nisi and $H$. columbae were found in the blood of some of wild birds sampled. However, clinical signs and pathological changes associated with haemoproteus infections, such as severe lameness, diarrhoae, severe depression, emaciation, anorexia, dyspnoae, sudden death, haemorrhages on the heart, oedematous lung, swollen firm livers, spleen and kidneys (Julian and Galt, 1980; Atkison and Forrester, 1987; Springer, 1997) were not observed in the wild birds studied in this experiment.

Newcastle disease (ND) is a dreaded disease of birds. It causes great losses in poultry industry due to high morbidity and mortality rates (Oladele et al., 2008; Ibu et al., 2009). It is believed that $\mathrm{HI}$ antibodies titre of greater than $\log _{2} 4.00$ in the sera of birds that are not vaccinated can cause the disease (Allan et al., 1978). It is interesting to note that in this study, some of the wild birds sampled, such as Laughing dove (Streptopelia senegalensis), Alleys galinue (Porphyrio alleni), Cut-throat finch (Amadina fasciata) and Senegal parrot (Poicephalus senegalus) had mean $\mathrm{HI}$ antibody titres of $\log _{2}$ $5.71 \pm 0.5, \log _{2} 6.00 \pm 0.1, \log _{2} 8.10 \pm 1.0$ and $\log _{2}$ $9.50 \pm 0.1$, respectively without showing any clinical signs or pathological changes associated with ND. Therefore, these species of wild birds could be sources of infection of NDV to domestic birds.

Since these wild birds sampled haboured these parasites without any obvious clinical or pathological changes, they could serve as reservoirs of avian malarial parasites, haemoproteid species and NDV, and consequently, these parasites could be transmitted by vectors or through contact to domestic birds, especially rural poultry, which constitute over $60 \%$ of total poultry population in Nigeria (Garba, 2008). The rural poultry are reared under free-range or backyard management system. Their movement is uncontrolled with little or no shelter, disease prophylaxis or veterinary care, thereby constantly exposing them to contact with wild birds and their waste products in their environment (Oladele and Ayo, 1999; Reed et al., 2003; Valkiu-Nas, 2005).

In conclusion, wild birds could serve as reservoirs of hemoparasites and viral pathogens that could be potential dangers to domestic birds in Zaria, Nigeria.

\section{Conflict of interest}

Authors declare that they have no conflict of interest.

\section{References}

1. Allan, W.H., Lancaster, J.E. and Toth, B. (1978), Newcastle disease vaccines - their production and use. FAO Animal Production and Health Series. No. 10, Rome, Italy.

2. Atkinson, C.T. and Forrester, D.J. (1987). Myopathy associated with megaloschizonts of haemoproteus meleagridis in wild turkeys from Florida. Journal of Wild Life Diseases, 23: 495-498.

3. Balash, J., Palacious, L.L., Musquera, S., Ralomeque, J., Menez, M.J. and Alemany, M. (1973). Comparative haematological values of several galliforms. Poultry Science, 52: 1531 - 
1534.

4. Beard, C.W. (1989). Serological procedures. In: A Laboratory Manual for Isolation and identification of Avian Pathogens (Purchase, H.G., L.H., Ard, C.H. Domermuth, J.E. Pearson, Eds.), American Association of Avian Pathologists, Kenneth Square, PA, United States of America, Pp. 192-200.

5. Benjamin, M.M. (1985). Outline of Veterinary Clinical Pathology, $3^{\text {rd }}$ ed. Kalyani Publishers, New Delhi, India.

6. Benneth, G., Okia, N.O. and Cameron, M.F. (1974). Avian haematozoa of some Ugandan birds. Journal of Wild Life Diseases, 10: 1955 1958.

7. Berthold, P., Bauer, H.G., and Westhead, V. (2001). Bird migration: A general survey. Oxford University Press, Oxford.

8. Campbell, T.W. and Coles, E.H. (1986). Avian clinical pathology. In: Veterinary Clinical Pathology (Coles, E.H., Ed.), W.B. Saunders Company, Philadelphia, Pp. 279-301.

9. Chamberlain, D.E., Vickery, J.A., Glue, D.E., Robinson, R.A., Conway, G.J., Woodburn, R.J. and Cannon, A.R. (2005). Annual and seasonal trends in the use of garden feeders by birds in winter. Ibis, 147; 563-575.

10. Clements, J.F. (2007). The Clements check-list of birds of the world, $6^{\text {th }}$ ed. Cornell University Press, Ithaca.

11. Dhama, K., Mahendran, M. and Tomar, S. (2008). Pathogens transmitted by migratory birds: Threat perceptions of poultry health and production. International Journal of Poultry Science, 7: 516-525.

12. Garba, A.M. (2008). Structure of poultry industry in Nigeria. Workshop Organized by ILRI-IFPRI, $17^{\text {th }}$ June, 2008, Ibadan, Nigeria, P.3.

13. Gill, F. (2006). Birds of the world: Recommended English names. Princeton University Press, Princeton.

14. Hubalek, Z. (2004). An annotated checklist of pathogenic micro-organisms associated with migratory birds. Journal of Wild Life Diseases, 40: 639-659.

15. Ibu, J.O., Okoye, J.O.A., Antiabong, J.F., Ayabi, G. and Oladele, S.B. (2009). Haemagglutinability of mammalian erythrocytes by Newcastle disease virus strains isolated from Central Nigeria. Archive of Veterinary Science, 14:57-62.

16. Julian, R.J. and Galt, D.E. (1980). Mortality in
Muscovy ducks (Carina moschata) caused by haemoproteus infection. Journal of Wild Life Diseases, 16: 39-44.

17. Keane, A., Brooke, M.D. and McGowan, P.J.K. (2006). Correlates of extinction risk and hunting pressure in gamebirds (Galliformes). Biological Conservation, 126: 216-233.

18. Newton, I. (2003). The speciation and biogeography of birds. Academic Press, Amsterdam, P. 463.

19. Oladele., S.B. and Ayo, J.O. (1999). Comparative studies on haematocrit, haemoglobin and total protein values of apparently healthy and clinically sick indigenous chickens in Zaria, Nigeria. Bulletin of Animal Health and Production in Africa, 47: 163-165.

20. Oladele, S.B., Raji, M.T. and Raji, M.A. (1999). Prevalence of bacterial and fungal microflora isolated from some wild and domesticated birds in Zaria, Nigeria. Bulletin of Animal Health and Production in Africa, 127-132.

21. Oladele, S.B., Enoch, I. and Ibrahim, N.D.G. (2008). Changes in histopathology, haematocrit, haemoglobin, haemagglutination inhibition antibody titre and total protein of Japanese quails (Coturnix coturnix japonica) administered different doses of Newcastle disease virus. Journal of Animal and Veterinary Advances, 7: 418-424.

22. Oladele, S.B. (2009). The significance of haematology in the diagnosis and therapy of avian diseases. A review. Nigerian Veterinary Journal, 30: 24-39.

23. Reed, K.D., Meece, J.K., Henke, J.S. and Shukla, S.K. (2003). Birds, migration and emerging zoonoses: West Nile virus, Lyme disease, influenza A and enteropathogens. Clinical and Medical Research, 1:5-12.

24. Sa'idu, L., Abdu, P.A., Umoh, J.U. and Abdullahi, U.S. (1994). Diseases of indigenous chickens. Bulletin of Animal Health and Production in Africa, 42: 19-23.

25. Shaffer, S.A., Trembley, Y. and Weimerskirch, H. (2006). Migratory shearwaters integrate oceanic resources across the Pacific Ocean in an endless summer. Proceedings of the National Academy of Science, 103: 12799-12802.

26. Spottiswoode, C. and Collebrook-Robjent, J. (2007). Egg puncturing by the blood parasites. Greater honey guide and potential host counter adaptations. Behaviorial Ecology, 10: 1093.

27. Springer, W.T. (1997). Other blood and tissue 
Pathogenic Haemoparasites and Antibody to Newcastle Disease from Apparently Healthy Wild Birds in Zaria,

protozoa. In: Diseases of Poultry. (Calnek, B.W., H.J. Barnes, C.W. Beard, L.R. McDougald, Y.M. Saif, Eds.) Iowa State University Press, Ames, Iowa, USA. Pp. 900-911.

28. Thrall, M.A. (2004). Veterinary hematology and clinical chemistry. Williams and Wilkins, Philadelphia, P. 518.
29. Walther, B.A. and Clayton, D.H. (2005). Laborate ornaments are costly to maintain: evidence for high maintenance handicaps. Behaviorial Ecology, 16: 89-95.

30. Weir, J.T. and Schluter, D. (2007). The latitudinal gradient in recent speciation and extinction rates of birds and mammals. Science, 315: 1574- 